\title{
Effectiveness of Nitrification Inhibition on Various Species of Brachiaria Grass Rhizosphere
}

\author{
Purwanto $^{1,{ }^{*}}$, Supriyadi ${ }^{1}$, and Aniek Hindrayani ${ }^{2}$ \\ ${ }^{1}$ Department of Soil Science, Sebelas Maret University, Surakarta - Indonesia \\ ${ }^{2}$ Department of Economic Education, Sebelas Maret University, Surakarta - Indonesia
}

\begin{abstract}
Nitrification has the potential to decrease the efficiency of nitrogen utilization by plants. The use of nitrifying inhibitory chemicals proved to be effective in controlling nitrification, but also affects beneficial soil microbes. Another attempt to inhibit the more environmentally-friendly nitrification is to use plants that have allelochemical nitrification inhibiting compounds such as the grasses of Brachiaria. The aim of this research is to know the effectivity of B.mutica, B.decumbens, and B.humidicola as inhibitors of nitrification rate in soil. The experiment was carried out by pot experimental method based on nondestructive sampling and Complete Randomized Design, consisting of Brachiaria plant types and various doses of $\mathrm{N}$ fertilizer, $100 \mathrm{~kg} / \mathrm{ha}, 150 \mathrm{~kg} / \mathrm{ha}, 200 \mathrm{~kg} / \mathrm{ha}$. The results of this study show that 1) B.mutica, B.decumbens, and B.humidicola, highly significant to the soil potential nitrification, but the treatment of various doses of $\mathrm{N}$ fertilizer is not significant to the soil potential nitrification. 2) the highest soil potential nitrification in B.mutica rhizosphere was $5.160 \mathrm{mg} \mathrm{NO}{ }_{2}{ }^{-} / \mathrm{g}$ of soil $/ 5 \mathrm{~h}$, while the lowest soil potential nitrification in the rhizosphere of B.humidicola plant was $0.414 \mathrm{mg} \mathrm{NO}_{2}{ }^{-} / \mathrm{g} / 5 \mathrm{~h}$. 3) From the four treatment of Brachiaria plants can be concluded B.humidicola plant more effective in inhibition of nitrification.
\end{abstract}

\section{Introduction}

One of the main problems in agricultural cultivation is low nitrogen $(\mathrm{N})$ used efficiency due to loss of $\mathrm{N}$ through nitrification, erosion, leaching and volatilization [1]. Approximately $67 \%$ of $\mathrm{N}$ fertilizers in the world's cereal crops (equivalent to US \$ 15.9 billion year-1) are leached in $\mathrm{NO}_{3}^{-}$form, volatilized as $\mathrm{NH}_{3}, \mathrm{~N}_{2} \mathrm{O}$ and $\mathrm{N}_{2}$ gases and lead to complex environmental problems [2]. Chemical compounds of nitrification inhibitors that have been developed include nitrapyrin, dicyandiamide (DCD) and 3,4-dimethyl-pryrazole-phosphate (DMPP) [1]. Although these synthetic compounds effectively reduce soil $\mathrm{N}$ losses, they have negative impacts on nontargeting microbes such as $\mathrm{N}_{2}$ fixing (diazotroph) bacteria and mycorrhiza fungi [3]. Several types of grasses Brachiaria (B. decumben, B. humidicola and $B$. brizantha) have been shown to be effective in inhibiting nitrification in the rhizosphere plant [1], [4], [5].

Researchers wanted to get models to improve nitrogen use efficiency and nitrate leaching by utilizing $B$. mutica, $B$. decumbens and $B$. humidicola as nitrification inhibitor plants. The purpose of this study was to determine the effectiveness of the rhizosphere of $B$. mutica, B. decumbens and B. humidicola in inhibiting nitrification in various doses of nitrogen fertilizer, whether the root activity of $B$. mutica, B. decumbens and $B$. humidicola plants were able to inhibit the nitrification of Alfisols soil. Of the three plants tested, researchers wanted to know which species of Brachiaria was most effective in inhibiting nitrification in Alfisols soil.
This research method is experimental pots in green house. The results of this study showed that $B$. mutica, $B$. decumbens, and $B$. humidicola, capable of inhibiting nitrification are shown with the result of all three having a very significant effect on the potential of nitrification; $B$. humidicola with a fertilization dose of $\mathrm{N} 200 \mathrm{~kg} / \mathrm{ha}$ is most effective in inhibition of nitrification, indicated by the lowest nitrification potential value of $0.414 \mathrm{mg} \mathrm{NO}_{2}^{-}$ /g soil/5 hours.

\section{Methods}

The detail of the experiment is as follows:

\subsection{Experimental Design}

\subsubsection{Material}

Materials used for this research were $B$. mutica, $B$. decumbens and $B$. humidicola, and chemical for laboratory analysis. The soil used in this study is Alfisols.

\subsubsection{Research Design}

This research is a pot experiment with functional relationship with variable approach based on nondestructive sampling and using factorial Completely Randomized Design (CRD). The treatment factor of this research is the combination of planting of three species of Brachiaria plant, namely B. mutica, B. decumben and $B$. humidicola, with the use of three different $\mathrm{N}$ fertilizer

Corresponding author: purwahadi@yahoo.com 
doses of $100 \mathrm{~kg} / \mathrm{ha}, 150 \mathrm{~kg} / \mathrm{ha}$ and $200 \mathrm{~kg} / \mathrm{Ha}$, so there are 9 (nine) different treatments with the control without plants and without fertilizer. Each treatment was repeated three times to obtain 30 treatments.

Table 1. Combination Treatment Factor of Plant Type and Urea Fertilizer Dose

\begin{tabular}{lcccc}
\hline & \multicolumn{4}{c}{ Dose of Urea Fertilizer as a source of N } \\
\cline { 2 - 5 } \multicolumn{1}{c}{$\begin{array}{c}\text { Types of } \\
\text { plants }\end{array}$} & $\begin{array}{c}\mathrm{N} 0 \\
(0 \mathrm{~kg} / \mathrm{ha})\end{array}$ & $\begin{array}{c}\mathrm{N} 1 \\
(100 \mathrm{~kg} / \mathrm{ha})\end{array}$ & $\begin{array}{c}\mathrm{N} 2 \\
(150 \mathrm{~kg} / \mathrm{ha})\end{array}$ & $\begin{array}{c}\mathrm{N} 3 \\
(200 \mathrm{~kg} / \\
\mathrm{ha})\end{array}$ \\
\hline $\begin{array}{l}\mathrm{B} 1(B . \\
\text { mutica })\end{array}$ & $\mathrm{B} 1 \mathrm{~N} 0$ & $\mathrm{~B} 1 \mathrm{~N} 1$ & $\mathrm{~B} 1 \mathrm{~N} 2$ & $\mathrm{~B} 1 \mathrm{~N} 3$ \\
$\begin{array}{l}\mathrm{B} 2(B . \\
\text { mecumbens })\end{array}$ & $\mathrm{B} 2 \mathrm{~N} 0$ & $\mathrm{~B} 2 \mathrm{~N} 1$ & $\mathrm{~B} 2 \mathrm{~N} 2$ & $\mathrm{~B} 2 \mathrm{~N} 3$ \\
$\begin{array}{l}\mathrm{B} 3(\text { B. } \\
\text { humidicola })\end{array}$ & $\mathrm{B} 3 \mathrm{~N} 0$ & $\mathrm{~B} 3 \mathrm{~N} 1$ & $\mathrm{~B} 3 \mathrm{~N} 2$ & $\mathrm{~B} 3 \mathrm{~N} 3$ \\
\hline
\end{tabular}

\subsubsection{Data Analysis}

Table 2. Methods and Units for Measuring Treatment Variables

\begin{tabular}{lcl}
\hline Parameter & Units & \multicolumn{1}{c}{ Method } \\
\hline $\mathrm{pH} \mathrm{H} \mathrm{H}_{2} \mathrm{O}$ & $\mathrm{pH}$ & $1: 2.5$ (soil $\left.: \mathrm{H}_{2} \mathrm{O}\right)$ \\
$\begin{array}{l}\text { Organic } \\
\text { Matter }\end{array}$ & $\%$ & Wet oxidation \\
$\mathrm{CEC}$ & $\mathrm{cmol} \mathrm{kg}^{-1}$ & Elektrometric \\
Base & $\%$ & Titration \\
Saturation & & \\
Organic-C & $\mathrm{g} \mathrm{kg}^{-1}$ & Wet oxidation \\
Total-N & $\mathrm{g} \mathrm{kg}^{-1}$ & \\
$\begin{array}{l}\text { Nitrification } \\
\text { Potential }\end{array}$ & $\mathrm{mg} \mathrm{NO}_{2}^{-} / \mathrm{g}$ & Schinner et al.,. \\
& soil/ 5 & \\
\hline hours & \\
\hline
\end{tabular}

The data of the research were analyzed with F 5\% test to know the difference between the treatments. Calculation and comparison between treatments done with Duncan Multiple Range Test (DMRT) 5\%. Data analysis used Minitab14 and Excel software.

\subsection{Experiment Implementation}

The experiments were conducted with the following stages:

(1) Initial soil sampling, to find out Organic-C, total-N, available- $\mathrm{N}$ (nitrate and ammonium), $\mathrm{CEC}, \mathrm{C} / \mathrm{N}$ ratio, $\mathrm{pH} \mathrm{H}_{2} \mathrm{O}$, temperature, and soil moisture.

(2) Preparation of planting media, the soil Alfisols that pass $2 \mathrm{~mm}$ sieve.

(3) Nitrogen fertilizer, ie urea fertilizer mixed into the soil before planting B. mutica, B. decumben and $B$. humidicola into the pot. Determination of nitrogen fertilizer is to meet the nutrient needs of Brachiaria plants as well as nitrification substrate. The doses administered were adjusted for each treatment.

(4) Planting of Brachiaria plants with plant propagation, then transferred into pots intact with the rhizosphere of the roots.

(5) Maintenance and irrigation by cleaning weeds and watering.
(6) Measurement of variables and soil sampling. Soil samples for potential nitrification measurements were taken aseptically at a depth of $0-20 \mathrm{~cm}$. Potential nitrification was measured from the amount of $\mathrm{NO}_{2}^{-}$formed from soil samples after added $\left(\mathrm{NH}_{4}\right)_{2} \mathrm{SO}_{4}$ and incubated at $25^{\circ} \mathrm{C}$ for 5 hours[6].

\section{Results and Discussion}

\subsection{Characteristics of Alfisols Soil}

Table 3. Result of Soil Analysis Before Treatment

\begin{tabular}{clcc}
\hline No & $\begin{array}{c}\text { Soil } \\
\text { Properties }\end{array}$ & Result & Valuation \\
\hline 1. & $\mathrm{pH} \mathrm{H} \mathrm{H}_{2} \mathrm{O}$ & 5.2 & Acid *) \\
2. & OM & $4.1 \%$ & Low *) \\
3. & CEC & $22.28 \mathrm{cmol} \mathrm{kg}^{-1}$ & Moderate $*)$ \\
4. & Base & $36 \%$ & Moderate *) \\
& Saturation & & \\
5. & Organic C & $3.89 \mathrm{~g} \mathrm{~kg}^{-1}$ & Moderate *) \\
6. & Total N & $0.28 \mathrm{~g} \mathrm{~kg}^{-1}$ & Moderate $*)$ \\
\hline
\end{tabular}

Source: Lab. Analysis

Note: *) Valuation according to the Soil Research Institute, 2009.

\subsection{The Influence of Various Brachiaria Plants to Soil Nitrification Potential}

The amount of $\mathrm{NO}_{2}^{-}$formed by a union of time, due to the biological $\mathrm{NH}_{4}{ }^{+}$oxidation process is called nitrification potential [6].

Table 4. Results of Nitrification Potential Diversity Analysis

\begin{tabular}{lcc}
\hline \multicolumn{1}{c}{ Source of Variations } & F test & P \\
\hline Plants & 18,27 & $0,000^{* *}$ \\
Fertilizer & 0,15 & $0,826^{\text {ns }}$ \\
Plants*Fertilizer & 1,00 & $0,416^{\text {ns }}$ \\
\hline
\end{tabular}

**: significant; ns: not significant

Table 4. shows that the Brachiaria plant species has a very significant effect on the value of soil nitrification potential $(\mathrm{P}<0.01)$. The treatment of various doses of nitrogen fertilizer as nitrification substrate proved to have no significant effect on the value of soil nitrification potential $(\mathrm{P}>0,05)$.

Table 5. Results of Diversity Analysis Influence of Planting of Some Species of Brachiaria Plants to Soil Nitrification Potential

\begin{tabular}{lcc}
\hline \multicolumn{1}{c}{ Source of Variations } & F tetst & P \\
\hline B. mutica & 20,14 & $0.000^{* *}$ \\
B. decunbens & 98,98 & $0.005^{* *}$ \\
B. humidocola & 21,75 & $0.009^{* *}$ \\
\hline
\end{tabular}

**: significant; ns: not significant. 
Table 6. Results of Potential Diversity Analysis of Nitrification Influence of Planting of Some Species of Brachiaria Plant on Each Incubation

\begin{tabular}{lcccccc}
\hline \multirow{2}{*}{$\begin{array}{c}\text { Source of } \\
\text { Variations }\end{array}$} & \multicolumn{5}{c}{$\begin{array}{c}\text { Nitrification Potential }\left(\mathrm{mg} \mathrm{NO}_{2} / \mathrm{g} \text { soil/5 }\right. \\
\text { hours) per incubation (Weeks) }\end{array}$} \\
\cline { 2 - 7 } B. mutica & $\mathbf{1}$ & $\mathbf{2}$ & $\mathbf{3}$ & $\mathbf{4}$ & $\mathbf{5}$ & $\mathbf{6}$ \\
\cline { 2 - 6 } B. decunben & $0.029^{*}$ & $0.010^{*}$ & $0.006^{* *}$ & $0.012^{*}$ & $0.012^{*}$ & $0.017^{*}$ \\
B. humidicola & $0.013^{*}$ & $0.007^{* *}$ & $0.000^{* *}$ & $0.006^{* *}$ & $0.031^{*}$ & $0.061^{*}$ \\
& $0.018^{*}$ & $0.032^{*}$ & $0.073^{*}$ & $0.110^{\mathrm{ns}}$ & $0.100^{\mathrm{ns}}$ & $0.137^{\mathrm{ns}}$ \\
\hline
\end{tabular}

Note:*) significant;**)very significant; ns:not significant.

Based on result of analysis of variance Table 5 it is known that the planting of various Brachiaria have a very significant effect $(\mathrm{P}$ value $<0.01)$ to the potential of nitrification. The results of the analysis of variance of table 6 of the treatment of various Brachiaria species showed different effects on the potential value of nitrification at each incubation time. $B$. mutica plants at each incubation period showed a significant effect on the potential value of nitrification, and very significant during the third incubation period. Plant B. decumben at the second incubation until the fourth incubation showed a very significant effect $(P$ value $<0.01)$ on the nitrification potential, whereas for $B$. humidicola plant the fourth incubation until the end of incubation did not significantly affect the nitrification potential.

Differences in the effect of planting of various Brachiaria plants during the incubation period can be indicated that each of the Brachiaria plant rhizosphere has different inhibitory activities.

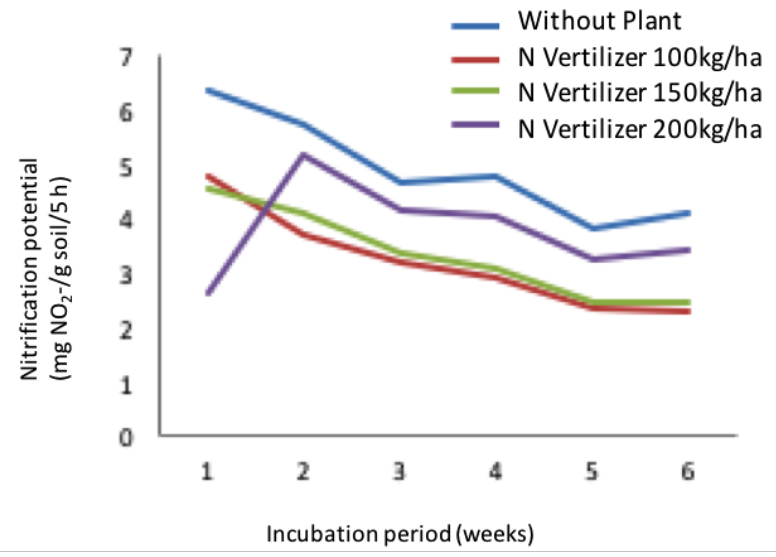

Fig. 1. Potential Nitrification $\left(\mathrm{NO}_{2}^{-}\right)$of soil in Brachiaria mutica plant per incubation time

The potential value of nitrification of $B$. mutica plants has a similar pattern at each $\mathrm{N}$ fertilization dose, except in the $\mathrm{N}$ fertilizer treatment of $200 \mathrm{~kg} / \mathrm{ha}$ at incubation time of the first week showed the lowest nitrification potential value of $2.582 \mathrm{mg} \mathrm{NO}_{2}^{-} / \mathrm{g} / 5$ hours later Increased to the highest value of $5.160 \mathrm{mg} \mathrm{NO}_{2}^{-} / \mathrm{g}$ of soil/5 hours at the second incubation period, and subsequently began to decrease. The decrease in the potential value of nitrification after the third incubation period indicates the onset of inhibition of nitrification by the $B$. mutica root activity. Treatment of $B$. mutica cultivation with N $100 \mathrm{~kg} / \mathrm{ha}$ fertilization has the lowest nitrification potential value $\left(2,245 \mathrm{mg} \mathrm{NO}_{2}{ }^{-} / \mathrm{g}\right.$ of soil $/ 5$ hours in fifth incubation) compared with $\mathrm{N} 150 \mathrm{~kg} / \mathrm{ha}$ fertilizer and N $200 \mathrm{~kg} /$ ha fertilizer.

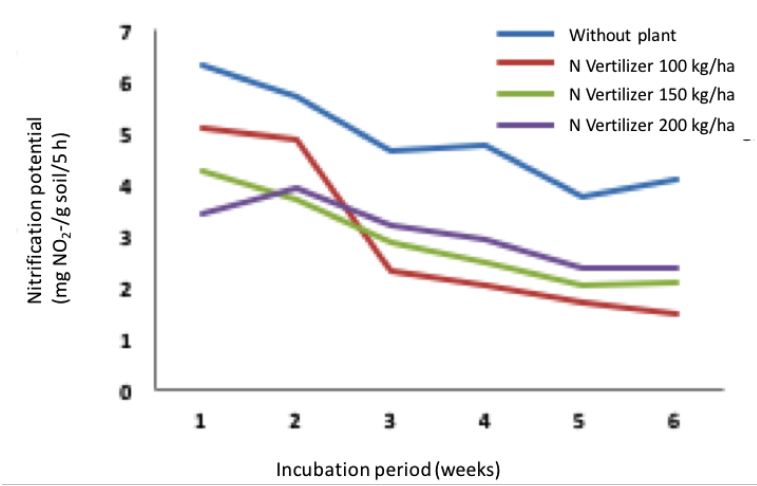

Fig. 2. Potential Nitrification $\left(\mathrm{NO}_{2}^{-}\right)$soil in Brachiaria decumben plant per incubation time

Figure 2 shows that the potential value of nitrification at planting $B$. decumben has a large value difference compared to the potential value of nitrification on soils without planting $B$. decumben. The highest value of $5.114 \mathrm{mg}$ of $\mathrm{NO}_{2}{ }^{-} / \mathrm{g}$ of soil $/ 5$ hours was found in the first $\mathrm{N} 100 \mathrm{~kg} / \mathrm{ha}$ incubation fertilization treatment, but then it will substantially decrease from the second incubation to the sixth week. In the third incubation period until the last incubation period the measured potential value of nitrification was $1.493 \mathrm{mg}$ $\mathrm{NO}_{2}{ }^{-} / \mathrm{g}$ of soil/5 hours. In general, treatment of addition of $\mathrm{N} 100 \mathrm{~kg} / \mathrm{ha}$ fertilizer has the lowest nitrification potential value from the addition of $\mathrm{N} 150 \mathrm{~kg} / \mathrm{ha}$ and $\mathrm{N}$ $200 \mathrm{~kg} / \mathrm{ha}$ fertilizer.

Based on figure 2 above it can also be seen that in each treatment, the decrease of potential nitrification value occurs in the third incubation which then shows a stable nitrification potential value until the end of incubation.

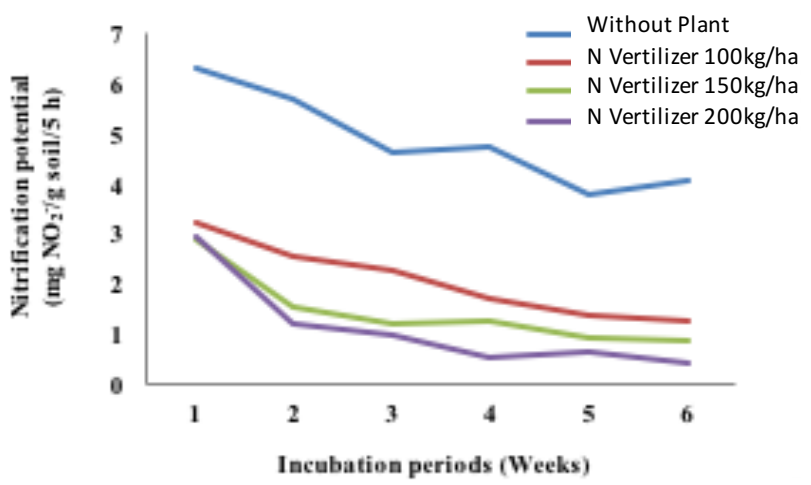

Fig. 3. Potential Nitrification $\left(\mathrm{NO}_{2}^{-}\right)$soil in Brachiaria humidicola plant per incubation time

From the observation of potential value of soil nitrification on $B$. humidicola plant has a measured value that is much lower than the potential value of soil nitrification without planting Brachiaria species. The potential value of nitrification on the $\mathrm{N} 200 \mathrm{~kg} / \mathrm{ha}$ fertilizer treatment was the lowest compared to the treatment of $\mathrm{N} 100 \mathrm{~kg} / \mathrm{ha}$ and $150 \mathrm{~kg} / \mathrm{ha}$, ie $0.414 \mathrm{mg}$ $\mathrm{NO}_{2}{ }^{-} / \mathrm{g} / 5$ hours. In the treatment of $B$. humidicola plant it 
can be seen that the decrease of nitrification potential indicates a value that is not too different from each incubation.

Treatment with planting of three types of Brachiaria plants showed a lower nitrification potential $\left(\mathrm{NO}_{2}{ }^{-}\right)$value than a plantless and non-fertilized treatment. This indicates that all three species of Brachiaria plants are capable of inhibiting nitrification. Soil without Brachiaria plants assumed to be a common condition of Alfisols soil proved to show a high potential value of nitrification. The activity of root exudate of $B$. humidicola plant is able to decrease $\mathrm{NO}_{2}^{-}$quantities in soil during incubation period, compared with control ${ }^{[16]}$. This suggests that the hydrolysis of $\mathrm{N}$-fertilizers in soils at $B$. humidicola planting treatment is still largely in $\mathrm{NH}_{4}$ + and not oxidized to $\mathrm{NO}_{3}^{-}$

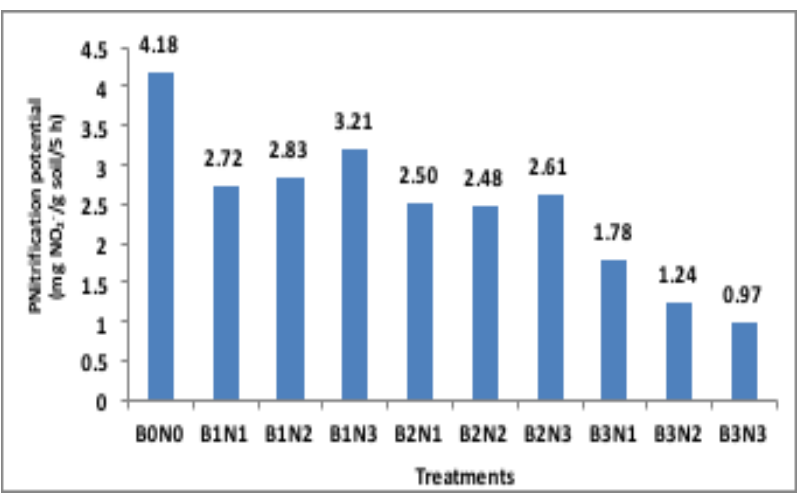

Fig. 4. Potential Nitrification at Various Treatments

From the average range of treatments compared with control (without crops and without fertilizers) showed that treatment with the Brachiaria plant had a lower nitrification potential value than that of non-plant treatment. This is because most of $\mathrm{NH}_{4}{ }^{+}$of urea fertilizer will be utilized as nitrification substrate so the nitrification potential is higher than treatment with Brachiaria plant. In the three treatments of the Brachiaria plant, (Figure 4), the treatment of B. mutica plants has a higher nitrification potential value, followed by the treatment of B. decumben and B. humidicola plants.

The average number of potential nitrification (3.21 mg NO$/ 2$ soil/5 hour) on a variety of plant species Brachiaria of the entire incubation period is the planting of $B$. mutica treatment with dosages of $200 \mathrm{~kg} / \mathrm{ha}$, while the lowest value $\left(0.97 \mathrm{mg} \mathrm{NO}_{2}^{-} / \mathrm{g}\right.$ of soil/5 hours) was found in the treatment of $B$. humidicola with fertilizer $\mathrm{N}$ $200 \mathrm{~kg} / \mathrm{ha}$.

The treatment plant B. mutica and B. decumben with fertilizer dose of $200 \mathrm{~kg} \mathrm{~N} /$ ha shows nitrification potential value that is greater than the treatment plant $B$. mutica and $B$. decumben with fertilizer dose of $100 \mathrm{~kg}$ $\mathrm{N} / \mathrm{ha}$ and a dose of fertilizer $\mathrm{N} 150 \mathrm{~kg} / \mathrm{Ha}$. This is thought to be due to a larger $\mathrm{N}$ source so that inhibition of nitrification is less effective than the treatment of smaller $\mathrm{N}$ fertilizer doses. Based on comparative test (DMRT 5\%) between interaction treatment of various species of Brachiaria and $\mathrm{N}$ fertilization dose to nitrification potential showed no significant difference.
Figure 4 shows that $B$. humidicola plant yields the lowest potential nitrification potential of the two other Brachiaria species. The rhizosphere activity of the three $B$. mutica, B. decumben and B. humidicola plants was shown to have a lower nitrification potential value than the non-plant and without fertilizer treatment. $B$. humidicola plant looks most effective in inhibiting nitrification with nitrification potential value of the lowest $\left(0.414 \mathrm{mg} \mathrm{NO}_{2}{ }^{-} / \mathrm{g}\right.$ soil $/ 5$ hour) at a dose of fertilizer $\mathrm{N} 200 \mathrm{~kg} / \mathrm{ha}$ than B. mutica and B. decumben.

Some of these nitrifying inhibitors have been isolated and identified from plant root exudates using bioassay purification tests. Biological nitrification inhibitor compound at several plants Brachiaria, have been identified in the form of free fatty acids are unsaturated[7],[8],[9],[10]. In a further study, it was found to be more specific that $B$. humidicola plants contain linoleic and alpha-linoleic acid compounds in appropriate amounts as a nitrification inhibitor. Nitrification inhibitors compound inhibit the chain allows the enzyme ammonia monooxygenase (AMO) and the enzyme hydroxylamin oxidoreductase (HAO) on nitrification [7], [11].

By proving the nitrification inhibition of various plant species Brachiaria in this study is expected to be developed model of the nitrification inhibition by utilizing Brachiaria plant as a crop mix (multiple cropping) together with other types of forage crops or other crops so as to increase the effectiveness of the use of fertilizer $\mathrm{N}$.

\section{Conclusion}

Nitrification is an adverse process in relation to the nitrogen use efficiency of plant and raises complex environmental problems. This study aims to find a way of controlling biological nitrification that is environmentally friendly by utilizing plants that produce alelochemical nitrification inhibitors compounds. The study was conducted by pots experiments in a greenhouse.

The research result of a variety Brachiaria planting with various doses of fertilizer $\mathrm{N}$ sources indicate that: (1) B. mutica, B. decumben, and B. humidicola plant, capable of inhibiting nitrification is indicated by the results of three very significant effect on nitrification potential; (2) B. humidicola with a dose of fertilizer $\mathrm{N}$ $200 \mathrm{~kg} / \mathrm{ha}$ of the most effective in the inhibition of nitrification, nitrification potential value indicated by the low at $0.414 \mathrm{mg} \mathrm{NO}{ }_{2}{ }^{-} / \mathrm{g}$ soil $/ 5$ hours. B. humidicola planting as mixed crops along with other types of grasses or other cultivation plants can be used to increase the efficiency of $\mathrm{N}$ nutrient utilization in the soil. To ensure the effectiveness of nitrification inhibition in the rhizosphere of Brachiaria plants need to do further research on the influence of the rhizosphere of various Brachiaria species on the ratio of $\mathrm{NH}_{4}^{+}$and $\mathrm{NO}_{3}$ content in soil (actual Nitrification in soil).

\section{References}


1. T. Watanabe, I. Osamu, World Journal of Agricultural Science, 4, 1, 106-113 (2008)

2. W.R. Raun and G.V. Johnson, Agronomy Journal, 91, $357-363,(1999)$

3. M. Rao, T. Ishikawa, O. Ito, M.P. Hurtado, E. Amezquita, E. Barrios, and C. Lascano, JIRCAS Working Report 71, 107-112 (2009)

4. T. Ishikawa. JIRCAS Research Highlight News Letter, 6 (3), 3 (1999)

5. V. Damin, H.C.J. Franco, M.F. Moraes, A. Franco, P.C.O. Trivelin. Agriculture Sci., 65, 4, 402-407 (2008)

6. F. Schinner, R. Ohlinger, E. Kandeler, and R. Mergesin, (eds.) Methods in Soil Biology, SpringerVerlag Berlin Heidelberg, 146-149 (1995)

7. G.V. Subbarao, M. Kishii, K. Nakahara, T. Ishikawa, T. Ban, H. Tsujimoto, T. S. George, W. L. Berry, CT Hash, and O. Ito, Breeding Science 59, 529-545 (2009)

8. G.V. Subbarao, M. Rondon, O. Ito, T. Ishikawa, M. Rao, K. Nakahara, C. Lascano, and W.L. Berry. Plant Soil, 294, 5-18 (2007)

9. G.V. Subbarao, T. Ishikawa, K. Nakahara, O. Ito, M. Rondon, I.M. Rao, and C. Lascano, JIRCAS Working Report, 51, 99-106 (2007)

10. S.T. Gopalakrishnan, S.J. Watanabe, Pearse, O. Ito, Z.A.K.M. Hossain, and G.V. Subbarao. Soil Science. Plant Nutr, 55, 725-733 (2009)

11. B. Tomohiro, K. Masahiro, O. Ito, H. Samejima, H.Y. Wang, S.J. Pearse, S. Gopalakrishnan, K.
Nakahara, A.K.M. Zakir Hossain, H. Tsujimoto, and W.L. Berry, Plant Soil, 310, 55-64 (2008)

12. A.J. Erickson, R.S. Ramsewak, A.J. Smucker, and M.G. Nair, 2000. Journal of Agricultural and Food Chemistry. 48, 12 6174-6177 (2000)

13. A.M. Fernandez, Souza, EFC. Gabriel, A, Marcelo, and A. Ciro, (Rosolem World Congress of Soil Science, Soil Solutions for a Changing World. Brisbane, Australia, 2010)

14. D.I. Dinnes, D.L. Karlen, D.B. Jaynes, T.C. Kaspar, J.L. Hatfield, T.S. Colvin, and C.A. Cambardella, Agronomy Journal, 94, 153-171 (2002)

15.G.V. Subbarao, K Nakahara, T. Ishikawa, T. Yoshihashi, O. Ito, H. Ono, M. OhnishiKameyama, M. Yoshida, N. Kawano, and W.L. Berry, Plant Soil, 313, 89-99 (2008)

16. I.R.P. Fillery, Plant Soil, 318, 1-4 (2009)

17. J.A. Delgado, A.R. Mosier, Journal on Environmental Quality, 25 (5). 1105 - 1111 (1996)

18. S.J. Dennis, K.C. Cameron, H.J. Di, J.L. Moir, V. Staples, P. Sills, and K.G. Richards, Biology and The Environment, 112B, 79-89 (2012)

19. S. Warneke, L.A. Schipper, D.A. Bruesewitz, I. McDonald, S. Cameron, Ecol Eng, 37, 511-522 (2011)

20. Soil Research Institute, Technical Guidelines for Soil Chemical Analysis, Plants, Water and Fertilizers. Soil Research Institute. Agency for Agricultural Research and Development. Ministry of Agriculture, Bogor (2009) 